\title{
Eribulin-induced Interstitial Pneumonia: A Case Series and Retrospective Cohort Study
}

\author{
Manabu Murakami ${ }^{1}$, Hiroaki Kanemura ${ }^{1}$, Yutaka Tomishima ${ }^{1}$, \\ Eriko Nakano ${ }^{2}$ and Tomohide Tamura ${ }^{1}$
}

\begin{abstract}
:
Eribulin is a chemotherapeutic agent used for advanced breast cancer, but there are some reports of eribulin-induced lung injuries. Three of our patients experienced eribulin-related lung injuries. Radiology revealed organizing pneumonia in two cases and diffuse ground-glass shadows indicative of hypersensitivity pneumonitis in the third. A retrospective survey of patients treated with eribulin at our hospital identified no other cases of eribulin-induced lung injuries. Overall, drug-related lung injuries occurred in $2.8 \%$ of our eribulin-treated patients, which is similar to the rates reported for other anticancer drugs. The findings from these three cases provide guidance for the safe use of eribulin.
\end{abstract}

Key words: eribulin, interstitial pneumonia, breast cancer

(Intern Med 59: 563-567, 2020)

(DOI: 10.2169/internalmedicine.2779-19)

\section{Introduction}

Breast cancer is reportedly the most common cancer in women in developed countries, and eribulin is an important drug for metastatic breast cancer (1-5). A phase I clinical trial of eribulin did not report interstitial pneumonia as an adverse event (1). A phase II clinical trial of eribulin in Japan reported one case of eribulin-induced lung injury (2); its frequency was $1.2 \%$ (2). In another phase II clinical trial and phase III trial of eribulin, we confirmed that 1 patient had interstitial pneumonia as an adverse event, and its frequency was $0.1 \%(3,4)$. In addition, according to the package insert of eribulin, the frequency of interstitial pneumonia as a side effect is $1.5 \%$ (5). This frequency is calculated on the basis of the number of patients confirmed to have interstitial pneumonia in previous clinical trials.

A postmarketing survey by a pharmaceutical company involving 961 patients who received eribulin for breast cancer between July 19, 2011, and May 14, 2012, reported 7 cases of interstitial pneumonia, and the frequency was $0.7 \%$ (6). One case resulted in a fatal outcome (6). To date, only two case reports of eribulin-induced lung disease have been pub- lished, and both described cases of interstitial pneumonia with radiological findings consistent with organizing pneumonia $(\mathrm{OP})(7,8)$.

In our hospital we have experienced three patients with eribulin-induced lung injuries (Table 1). We herein report these cases and the results of a retrospective medical chart review conducted to determine the frequency of eribulininduced interstitial pneumonia in our hospital.

\section{Case Reports}

\section{Case 1}

A 72-year-old Japanese woman with advanced breast cancer presented with exertional dyspnea and a productive cough 5 days after receiving an intravenous eribulin infusion $\left(1.4 \mathrm{mg} / \mathrm{m}^{2}\right)$. On postinfusion day 7 , she was febrile with an $88 \%$ arterial oxygen saturation level while breathing ambient air. Her Eastern Cooperative Oncology Group (ECOG) performance status was 0 . Immunohistochemical staining revealed that she was positive for estrogen receptor and progesterone receptor and negative for human epidermal growth factor receptor type 2 (HER2). Skin metastasis and axillary/

${ }^{1}$ Department of Pulmonary Medicine, Thoracic Center, St. Luke's International Hospital, Japan and ${ }^{2}$ Division of Medical Oncology, St. Luke's International Hospital, Japan

Received: February 2, 2019; Accepted: August 27, 2019; Advance Publication by J-STAGE: October 7, 2019

Correspondence to Dr. Hiroaki Kanemura, whitetigerblink@gmail.com 
Table 1. Summary of Patient Characteristics with Interstitial Pneumonia during Use of Eribulin.

\begin{tabular}{|c|c|c|c|c|c|c|}
\hline Case & Sex & $\begin{array}{l}\text { Age } \\
\text { years }\end{array}$ & Time of onset & $\begin{array}{l}\text { Peak Krebs von } \\
\text { den Lungen-6 }\end{array}$ & $\begin{array}{l}\text { Chest CT } \\
\text { Images }\end{array}$ & Treatments \\
\hline 1 & Female & 72 & $\begin{array}{l}\text { Seven days after The First } \\
\text { administration of Eribulin }(1.4 \mathrm{mg} / \\
\mathrm{m}^{2} \text { administered intravenously } \\
\text { during } 2-5 \text { minutes) }\end{array}$ & $\begin{array}{l}\text { 2,961 IU/mL } \\
\text { (After } 2 \text { weeks } \\
\text { from diagnosis) }\end{array}$ & $\begin{array}{l}\text { Organized } \\
\text { pneumonia } \\
\text { pattern }\end{array}$ & $\begin{array}{l}\text { - Discontinuation of Eribulin administration } \\
\text { Methylprednisolone } 60 \mathrm{mg} / \text { day } \\
\text { - Steroid was decreased gradually and } \\
\text { stopped about one month later }\end{array}$ \\
\hline 2 & Female & 73 & $\begin{array}{l}\text { The eighth course administration of } \\
\text { Eribulin ( } 1.4 \mathrm{mg} / \mathrm{m}^{2} \text { administered } \\
\text { intravenously during } 2-5 \text { minutes on } \\
\text { days } 1 \text { and } 8 \text { of a } 21 \text {-day cycle) }\end{array}$ & $\begin{array}{l}581 \mathrm{IU} / \mathrm{mL} \\
\text { (After } 2 \text { weeks } \\
\text { from diagnosis) }\end{array}$ & $\begin{array}{l}\text { Hypersensitivity } \\
\text { pneumonia } \\
\text { pattern }\end{array}$ & $\begin{array}{l}\text { - Discontinuation of Eribulin administration } \\
\text { - Careful attention }\end{array}$ \\
\hline 3 & Female & 72 & $\begin{array}{l}\text { Seven days after the forth course } \\
\text { administration of Eribulin }(1.4 \mathrm{mg} / \\
\mathrm{m}^{2} \text { administered intravenously } \\
\text { during } 2-5 \text { minutes on days } 1 \text { and } 8 \\
\text { of a } 21 \text {-day cycle) }\end{array}$ & $\begin{array}{l}1,001 \mathrm{IU} / \mathrm{mL} \\
\text { (After } 3 \text { days } \\
\text { from diagnosis) }\end{array}$ & $\begin{array}{l}\text { Organized } \\
\text { pneumonia } \\
\text { pattern }\end{array}$ & $\begin{array}{l}\text { - Discontinuation of Eribulin administration } \\
\text { - Methylprednisolone } 1,000 \mathrm{mg} / \text { day } \\
\text { - Steroid was decreased gradually four two } \\
\text { months }\end{array}$ \\
\hline $\begin{array}{l}\text { A case of } \\
\text { another } \\
\text { report (7) }\end{array}$ & Female & 52 & $\begin{array}{l}\text { Five days after the second course } \\
\text { administration of Eribulin }(1.4 \mathrm{mg} / \\
\mathrm{m}^{2} \text { administered intravenously } \\
\text { during } 2-5 \text { minutes on days } 1 \text { and } 8 \\
\text { of a } 21 \text {-day cycle) }\end{array}$ & 3,782 IU/mL & $\begin{array}{l}\text { Organized } \\
\text { pneumonia } \\
\text { pattern }\end{array}$ & $\begin{array}{l}\text { - Discontinuation of Eribulin administration } \\
\text { - Methylprednisolone } 1 \mathrm{mg} / \mathrm{kg} / \mathrm{day}\end{array}$ \\
\hline $\begin{array}{l}\text { A case of } \\
\text { another } \\
\text { report ( } 8)\end{array}$ & Female & 48 & $\begin{array}{l}\text { Six days after the first course } \\
\text { administration of Eribulin }(1.4 \mathrm{mg} / \\
\mathrm{m}^{2} \text { administered intravenously } \\
\text { during } 2-5 \text { minutes on days } 1 \text { and } 8 \\
\text { of a } 21 \text {-day cycle) }\end{array}$ & $206 \mathrm{IU} / \mathrm{mL}$ & $\begin{array}{l}\text { Organized } \\
\text { pneumonia } \\
\text { pattern }\end{array}$ & $\begin{array}{l}\text { - Discontinuation of Eribulin administration } \\
\text { - Careful attention }\end{array}$ \\
\hline
\end{tabular}

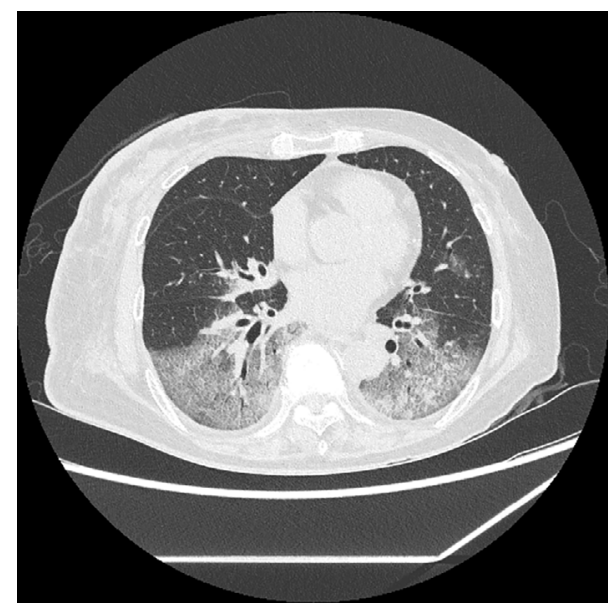

Figure 1. Axial chest computed tomography scan of Case 1: organizing pneumonia pattern.

mediastinum/hilar lymph node metastasis were observed. No drugs other than eribulin had been recently administered. As treatment for breast cancer, hormone therapy and chemotherapy with anthracycline and taxane, including anaztorozole, tamoxifen, medroxyprogesterone, fulvestrant, capecitabine, doxorubicin, cyclophosphamide, and paclitaxel, had been administered.

One month before eribulin infusion, irradiation of the right breast skin metastasis was performed. Auscultation revealed fine crackles in her bibasilar lung fields. No findings such as edema or jugular vein distention were noted. Laboratory tests showed a white blood cell count of $2,600 \mu \mathrm{L}^{-1}$, which is consistent with leukopenia; also noted were a lactate dehydrogenase level of $372 \mathrm{U} / \mathrm{L}$, serum plasma N- terminal pro-B-type natriuremic peptide level of $390.3 \mathrm{ng} / \mathrm{L}$, and a C-reactive protein level of $20.4 \mathrm{mg} / \mathrm{dL}$. Chest radiography revealed ground-glass shadows in both lung fields. Chest high-resolution computed tomography (CT) revealed consolidation with ground-glass shadows (i.e., an OP pattern) on the dorsal sides of both lungs (Fig. 1).

These findings led us to suspect that she had eribulininduced lung injuries rather than infectious pneumonia or heart failure, so we discontinued eribulin therapy and administered oxygen therapy and methylprednisolone at 60 $\mathrm{mg} /$ day. The lesions in both lungs were ameliorated by the 5 th day of treatment, and oxygen therapy became unnecessary on the 6th day of treatment. On the 11th day of treatment, the methylprednisolone dosage was reduced to $40 \mathrm{mg} /$ day, and the patient was discharged. Her methylprednisolone dosage was gradually tapered off over the following month. In addition, eribulin was not readministered. A drug-induced lymphocyte stimulation test for eribulin-induced effects in peripheral blood returned negative results. We did not plan to perform bronchoscopy because her respiratory condition had not been stable initially.

\section{Case 2}

A 73-year-old Japanese woman diagnosed with advanced breast cancer received an initial eribulin dose $\left(1.4 \mathrm{mg} / \mathrm{m}^{2}\right)$, and 24 weeks later, chest CT revealed diffuse ground-glass shadows [i.e., a hypersensitivity pneumonitis (HP) pattern] on the dorsal sides of both lungs (Fig. 2). Her ECOG performance status was 0 . Immunohistochemical staining revealed that she was positive for the estrogen receptor and progesterone receptor and negative for HER2. Metastatic lesions were found in the skin, axillary lymph node, and liver. 


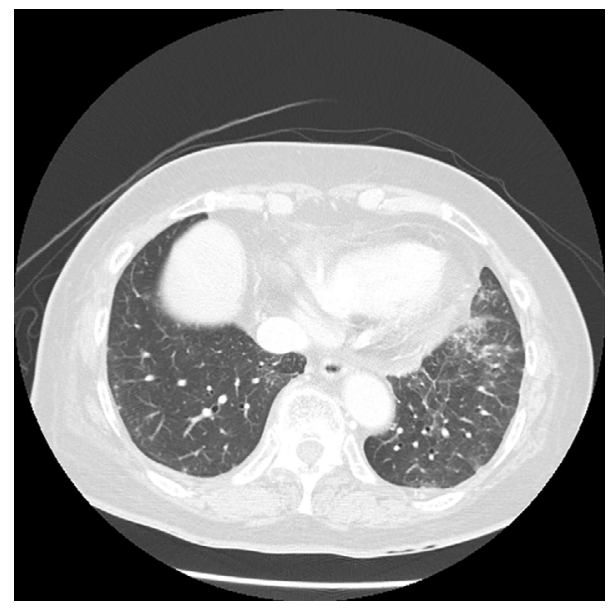

Figure 2. Axial chest computed tomography scan of Case 2: hypersensitivity pneumonitis pattern.

No medications other than eribulin had been recently administered. She had not previously received radiation therapy. Hormone therapy and chemotherapy with exemestane, anaztorozole, tamoxifen, toremifene, letrozole, medroxyprogesterone, fulvestrant, capecitabine, and paclitaxel had been administered for prior treatment of breast cancer. Her general condition was stable, and no signs of infection, renal failure, or heart failure were observed. Auscultation revealed fine crackles in her bibasilar lung fields. There were no congestive findings such as edema. Laboratory tests did not include evaluation of serum plasma N-terminal pro- B-type natriuremic peptide levels. We therefore suspected that she had eribulin-induced lung injuries.

Eribulin treatment was discontinued, and the diffuse ground-glass shadows disappeared within a month. Bronchoscopy and a drug-induced lymphocyte stimulation test for eribulin-induced effects in peripheral blood were not performed because we considered the lung injury likely to improve with only careful observation.

\section{Case 3}

A 72-year-old Japanese woman with advanced breast cancer presented with exertional dyspnea and a productive cough 7 days after receiving eribulin $\left(1.4 \mathrm{mg} / \mathrm{m}^{2}\right)$. Chest CT revealed consolidation with ground-glass shadows (i.e., an OP pattern) on the right side of the lung (Fig. 3). Her ECOG performance status was 0 . Immunohistochemical staining revealed that she was positive for the estrogen receptor and progesterone receptor and negative for HER2. Metastatic lesions were found in the bone, lung, left chest wall, axillary/mediastinum lymph node, and pleural effusion. No new drugs likely to cause drug-induced lung injury except for eribulin had been administered. Prior treatment for breast cancer involved hormone therapy and chemotherapy with letrozole, paclitaxel, tamoxifen, fulvestrant, doxorubicin, cyclophosphamide, and capecitabine. Auscultation revealed fine crackles in her right lung fields. She had not previously received radiation therapy. No findings such as

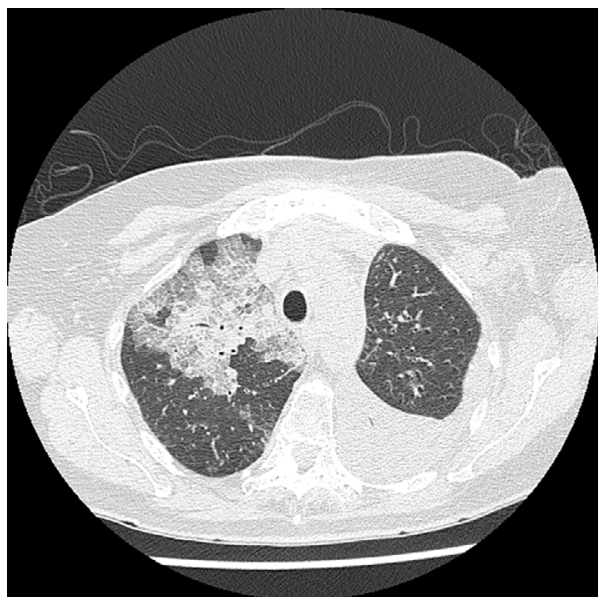

Figure 3. Axial chest computed tomography scan of Case 3: organizing pneumonia pattern.

edema or jugular vein distention were noted. The serum plasma $\mathrm{N}$-terminal pro-B-type natriuremic peptide levels was not evaluated.

Based on the diagnosis of eribulin-induced pneumonia, we discontinued eribulin therapy and initiated oxygen therapy and steroid pulse therapy. Eleven days later, she was discharged with prednisolone at $30 \mathrm{mg} /$ day. Considering her unstable respiratory condition, we did not perform bronchoscopy or a drug-induced lymphocyte stimulation test.

\section{Frequency of eribulin-induced lung injuries}

To determine the frequency of eribulin-induced lung injuries at our hospital, we conducted a retrospective chart review. The subjects were 121 patients who received eribulin for breast cancer at St. Luke's International Hospital between October 3, 2016, and May 29, 2018. We found no cases of eribulin-induced lung injuries apart from the three aforementioned cases. Of the 121 cases, 13 were excluded due to missing data. Table 2 shows the characteristics of the 108 remaining patients. The incidence rate of eribulininduced interstitial pneumonia at our hospital was $2.8 \%$. Because all 3 cases of eribulin-induced interstitial pneumonia developed at $\geq 70$ years of age, we performed further analyses to compare the background characteristics between patients $\geq 70$ years old and those $<70$ years old. Differences between the two age groups were assessed by Fisher's exact test for categorical variables and a $t$-test for continuous variables. All tests for significance were 2-tailed, with an $\alpha$ value of 0.05 . The R-3.5.2 software program was used for this statistical analysis. As shown in Table 3, the only statistically significant difference between the two age groups was in the development of eribulin-induced interstitial lung disease.

\section{Discussion}

Three of our patients experienced interstitial pneumonia that we suspected was caused by eribulin. These patients 
Table 2. Patient Demographics and Baseline Characteristics (Eligible Population: $\mathrm{N}=108$ ).

\begin{tabular}{|c|c|}
\hline Age, median (range), years & $52.0(27.0-84.0)$ \\
\hline Time since original diagnosis, median (range), years & $4.0(0.2-22.6)$ \\
\hline \multicolumn{2}{|l|}{ ECOG performance status, n (\%) } \\
\hline 0 & $68(70.0 \%)$ \\
\hline 1 & $32(29.6 \%)$ \\
\hline 2 & $6(5.6 \%)$ \\
\hline 3 & $2(1.9 \%)$ \\
\hline 4 & $0(0 \%)$ \\
\hline ER and/or PgR positive, n (\%) & $78(72.2 \%)$ \\
\hline HER2/neu positive (combined FISH and IHC tests), n (\%) & $21(19.4 \%)$ \\
\hline Triple-negative (HER2/neu, ER, PgR), n (\%) & $25(23.2 \%)$ \\
\hline \multicolumn{2}{|l|}{ No. of organs involved, $\mathrm{n}(\%)$} \\
\hline 1 & $10(9.3 \%)$ \\
\hline 2 & $35(32.1 \%)$ \\
\hline 3 & $30(27.8 \%)$ \\
\hline 4 & $18(16.7 \%)$ \\
\hline 5 & $11(10.2 \%)$ \\
\hline 6 & $3(2.8 \%)$ \\
\hline 7 & $1(0.9 \%)$ \\
\hline \multicolumn{2}{|l|}{ Most common metastatic sites, $\mathrm{n}(\%)$} \\
\hline Lymph nodes & $76(70.4 \%)$ \\
\hline Bone & $66(61.1 \%)$ \\
\hline Liver & $65(60.2 \%)$ \\
\hline Lung & $47(43.5 \%)$ \\
\hline Others & $46(42.6 \%)$ \\
\hline \multicolumn{2}{|l|}{ No. of prior anti-cancer drug regimens, $\mathrm{n}(\%)$} \\
\hline 1 & $4(3.7 \%)$ \\
\hline 2 & $16(14.8 \%)$ \\
\hline 3 & $14(13.0 \%)$ \\
\hline 4 & $14(13.0 \%)$ \\
\hline 5 & $14(13.0 \%)$ \\
\hline 6 & $19(17.6 \%)$ \\
\hline$\geq 7$ & $27(25.0 \%)$ \\
\hline Median (range) & $5(1-14)$ \\
\hline \multicolumn{2}{|l|}{ Prior anti-cancer drug agent, $\mathrm{n}(\%)$} \\
\hline Anthracycline & $89(82.4 \%)$ \\
\hline Taxane & $99(91.7 \%)$ \\
\hline Capecitabine & $41(38.0 \%)$ \\
\hline Vinorelbine & $16(14.8 \%)$ \\
\hline Tegafur/gimeracil/oteracil potassium & $10(9.3 \%)$ \\
\hline Gemcitabine & $13(12.0 \%)$ \\
\hline Hormonal drugs & $74(68.5 \%)$ \\
\hline Molecular targeted drugs & $18(16.7 \%)$ \\
\hline Others & $93(86.1 \%)$ \\
\hline Prior surgery, n (\%) & $83(76.9 \%)$ \\
\hline Prior radiotherapy, n (\%) & $71(65.7 \%)$ \\
\hline \multicolumn{2}{|l|}{ Eriblin course } \\
\hline 1 & $14(13.0 \%)$ \\
\hline 2 & $13(12.0 \%)$ \\
\hline 3 & $14(13.0 \%)$ \\
\hline 4 & $13(12.0 \%)$ \\
\hline 5 & $4(3.7 \%)$ \\
\hline$\geq 6$ & $50(46.3 \%)$ \\
\hline Median (range) & $5.0(1.0-65.0)$ \\
\hline \multicolumn{2}{|l|}{ Smoking History } \\
\hline Never & $93(86.1 \%)$ \\
\hline Former & $14(13.0 \%)$ \\
\hline Current & $1(0.9 \%)$ \\
\hline \multicolumn{2}{|l|}{ Lung Disease } \\
\hline None & $83(76.9 \%)$ \\
\hline Emphysema & $4(3.7 \%)$ \\
\hline Chronic bronchitis & $3(2.8 \%)$ \\
\hline Interstitial pneumonia & $18(16.7 \%)$ \\
\hline
\end{tabular}

ECOG: Eastern Cooperative Oncology Group, ER: oestrogen receptor, FISH: fluorescence in situ hybridisation, HER2/neu: human epidermal growth factor receptor 2, IHC: immunohistochemistry, PgR: progesterone receptor had no known lung disorders before the administration of eribulin, and they were not taking any other drugs prone to cause interstitial pneumonia. We did not observe any findings suggestive of infectious pneumonia, and culture tests of sputum and blood revealed no pathogenic bacteria. Two of these patients had CT findings that were very similar to those obtained in previously reported cases of eribulininduced interstitial pneumonia, and these two patients responded well to steroid treatment, as did the patients in past case reports. The other patient had radiological findings indicative of HP, and her condition improved after eribulin discontinuation. Taken together, these findings indicate that all three of these patients developed interstitial pneumonia due to eribulin.

Only two cases of eribulin-induced pulmonary injuries have been previously reported, and both of those cases featured radiological evidence of interstitial pneumonia with an OP pattern. Two of our patients had similar CT findings after receiving eribulin. We therefore speculate that an OP pattern of pulmonary damage is a characteristic of eribulininduced interstitial pneumonia.

The HP pattern is common in various forms of druginduced interstitial pneumonia, such as gemcitabine-induced pulmonary toxicity (9). However, to our knowledge, this is the first report of eribulin-induced interstitial pneumonia with radiological evidence of an HP pattern.

Among the three cases reported this time, in one case, the drug lymphocyte stimulation test (DLST) was performed, but the result was negative. The rate of positive results on the DLST for anticancer drugs has been reported to be $33.3 \%$ in the literature (10). Therefore, even though the DLST result was negative, it cannot be said that eribulin does not cause interstitial pneumonia.

In our hospital, the incidence rate of eribulin-induced interstitial pneumonia was $2.8 \%$. This is consistent with the literature concerning other anticancer drugs, for which the incidence rates for drug-induced pulmonary injuries range from $0.5 \%$ to $5 \%(11-13)$.

However, given that we encountered only three cases of eribulin-induced interstitial pneumonia, it might not be statistically appropriate to compare the characteristics between the patients with eribulin-induced interstitial pneumonia and those without eribulin-induced pulmonary injury. Instead, based on the finding that all patients with eribulin-induced interstitial pneumonia were $\geq 70$ years old, we compared the patients $\geq 70$ years old with those $<70$ years old in order to explore the risk of drug-associated pulmonary injury. As a result, the only significant difference between the two age groups was in the development of eribulin-induced interstitial pneumonia. Although we were unable to statistically adjust for other possible confounders because of the limited number of event cases, an advanced age may be associated with eribulin-induced interstitial pneumonia.

The characteristics of the present patients were not significantly different from those of patients in a previous study (2). The number of regimens tended to be higher than 
Table 3. Patient Group Comparison (Younger than 70 Years vs. 70 Years Old and Older than 70 Years).

\begin{tabular}{|c|c|c|c|}
\hline & $\begin{array}{l}\text { Younger than } 70 \text { years } \\
\qquad(\mathrm{n}=92)\end{array}$ & $\begin{array}{l}70 \text { years old and older than } \\
70 \text { years old }(n=16)\end{array}$ & $\mathrm{p}$ value \\
\hline ECOG performance status, median (range) & $0(0-3)$ & $0(0-3)$ & 0.422 \\
\hline Patients with lung metastasis, n (\%) & $41(44.6 \%)$ & $6(37.5 \%)$ & 0.786 \\
\hline No. of prior anti-cancer drug regimens, median (range) & $5(1-14)$ & $4(1-9)$ & 0.755 \\
\hline Prior radiotherapy, $\mathrm{n}(\%)$ & $63(68.5 \%)$ & $8(50.0 \%)$ & 0.164 \\
\hline Former+current smoker, $\mathrm{n}(\%)$ & $14(15.2 \%)$ & $1(6.3 \%)$ & 0.462 \\
\hline Background interstitial pneumonia, n (\%) & $15(16.3 \%)$ & $3(18.8 \%)$ & 0.728 \\
\hline Eribulin-induced interstitial pneumonia, n (\%) & $0(0 \%)$ & $3(18.8 \%)$ & 0.003 \\
\hline
\end{tabular}

ECOG: Eastern Cooperative Oncology Group

that reported in previous studies, probably because the treatment options for advanced breast cancer have increased over the past decade. The incidence rate of eribulin-induced interstitial pneumonia in our hospital tends to be higher than that reported in a prior phase II trial (2). Although no study has reported on the relationship between the incidence of druginduced interstitial pneumonia and the number of regimens, it is likely that the increase in the number of regimens contributed to the high incidence rate in our hospital.

Breast cancer is the most common cancer in women and is a major cause of cancer deaths (14). Eribulin is an important treatment for advanced breast cancer. Recognition of eribulin-induced lung injuries might improve the safety of women undergoing treatment for breast cancer.

The authors state that they have no Conflict of Interest (COI).

\section{References}

1. Toru M, Shunji N, Hirofumi M, et al. Eribulin mesylate in patients with refractory cancers: a Phase I study. Invest New Drugs 30: 1926-1933, 2012.

2. Aogi K, Iwata H, Masuda N, et al. A phase II study of eribulin in Japanese patients with heavily pretreated metastatic breast cancer. Ann Oncol 23: 1441-1448, 2012.

3. Cortes J, O'Shaughnessy J, Loesch D, et al. Eribulin monotherapy versus treatment of physician's choice in patients with metastatic breast cancer (EMBRACE): a phase 3 open-label randomised study. Lancet 377: 914-923, 2011.

4. Cortes J, Vahdat L, Blum JL, et al. Phase II study of the halichondrin $\mathrm{B}$ analog eribulin mesylate in patients with locally advanced or metastatic breast cancer previously treated with an anthracycline, a taxane, and capecitabine. J Clin Oncol 28: 3922-3928, 2010.
5. The package insert of eribulin [Internet]. [cited 2019 Jan 31]. Available from: http://www.info.pmda.go.jp/go/pack/4291420A102 2_1_07/ (in Japanese).

6. Post-marketing surveillance for the clinical safety and effectiveness of eribulin mesylate in patients with inoperable or recurrent breast cancer (Study HAL01S) [Internet]. [cited 2019 Jan 31]. Available from: https://clinicaltrials.gov/ct2/show/NCT01463891

7. Nakamura K, Kato M, Miyashita Y, et al. Development of interstitial pneumonia during treatment with eribulin: a case report. BMC Res Notes 10: 557, 2017.

8. Ishida $\mathrm{H}$, Honma $\mathrm{T}$, Ishida $\mathrm{K}$, et al. Pneumonia induced by eribulin mesylate in a patient with recurrent breast cancer. Int Canc Conf J 2: 135-138, 2013.

9. Tamura M, Saraya T, Fujiwara M, et al. High-resolution computed tomography findings for patients with drug-induced pulmonary toxicity, with special reference to hypersensitivity pneumonitis-like patterns in gemcitabine-induced cases. Oncologist 18: 454-459, 2013.

10. Kondo A. Drug-induced pneumonitis. Kekkaku (Tuberculosis) 74: 33-41, 1999 (in Japanese, Abstract in English).

11. Foucher P, Camus $P$. The drug-induced respiratory disease website. Pneumotox [Internet]. [cited 2019 Jan 31]. Available from: http://w ww.pneumotox.com

12. Camus $P$, Fanton $A$, Bonniaud $P$, et al. Interstitial lung disease induced by drugs and radiation. Respiration 71: 301-326, 2004.

13. Limper AH. Chemotherapy-induced lung disease. Clin Chest Med 25: 53-64, 2004.

14. Fitzmaurice C, Akinyemiju TF, et al.; Global Burden of Disease Cancer Collaboration. Global, regional, and national cancer incidence, mortality, years of life lost, years lived with disability, and disability-adjusted life-years for 29 cancer groups, 1990 to 2016: a systematic analysis for the Global Burden of Disease Study. JAMA Oncol 3: 524-548, 2017.

The Internal Medicine is an Open Access journal distributed under the Creative Commons Attribution-NonCommercial-NoDerivatives 4.0 International License. To view the details of this license, please visit (https://creativecommons.org/licenses/ by-nc-nd/4.0/).

\section{(C) 2020 The Japanese Society of Internal Medicine} Intern Med 59: 563-567, 2020 